\title{
DOES HEALTH MATTER? EVIDENCE FROM THE EU15 AND TURKEY
}

\author{
Asst. Prof. Tuğba AKIN \\ Aydın Adnan Menderes University, AFE, Aydın, Turkey, (tugba.akin@adu.edu.tr) \\ Res. Asst. Sedat ALATAŞ \\ Aydın Adnan Menderes University, NFEAS, Aydın, Turkey, (sedat.alatas@adu.edu.tr) \\ Res. Asst. Burcu YILMAZ \\ Aydın Adnan Menderes University, NFEAS, Aydın, Turkey, (burcu.yilmaz@adu.edu.tr)
}

\begin{abstract}
This study provides evidence on the role of health in accounting for income in sixteen countries (EU15 and Turkey). The relationship between health and income was analyzed with dynamic panel regression by using panel data for the 1970-2013 periods. The empirical evidence suggests that two health measures, life expectancy at birth and mortality rate have positive impacts on income. The estimates show that the relationship is even stronger for EU15 countries compared with Turkey.
\end{abstract}

Keywords: Health, Income, Panel Data Analysis, EU-15 Countries.

\section{SAĞLIK ÖNEMLI Mİ? AB-15 VE TÜRKIYY'DEN GELEN KANITLAR}

\begin{abstract}
ÖZET
Bu çalışma 16 ülkede (AB-15 ve Türkiye) gelirin hesaplanmasında sa ğlı ğın rolü hakkında kanıtlar sunmaktadır. Sağlık ve gelir arasındaki ilişki, dinamik panel regresyon yöntemi ve 1970-2013 dönemine ait panel veri seti kullanılarak analiz edilmiştir. Ampirik sonuçlar, să̆lık ile ilgili iki ölçümün, doğumda yaşam beklentisi ve ölüm oranı, gelir üzerinde pozitif etkisi olduğu yönündedir. Elde edilen tahminler, söz konusu ilişkinin Türkiye ile klyaslandı ğında AB15 ülkeleri için daha güçlü olduğunu göstermektedir.
\end{abstract}

Anahtar Kelimeler: Sa ğlık, Gelir, Panel Veri Analizi, AB-15 Ülkeleri. 


\section{Introduction}

Indeed all branches of economy deals with maximization of human prosperity. Besides economic developments, one of the most important factors that increase human well-being is health conditions. The improvement of health conditions effects not only human ability but also economic welfare in the long-term. Therefore, developments in health and the economy should not be considered independently from each other.

In the 20th century, positive advancements in the health sector reduced mortality rate in the worldwide and average human life expectancy rate has risen. At the beginning of 2000's, average life expectancy at the birth of the global population was 66.4 years. In 2015 global average life expectancy increased 5 years and it was recorded as 71.4 years (WHO, 2016). This significant increase was observed with global life expectancy because of a number of factors such as improvement in child survival, better nutrition and health conditions, success in the fight against diseases, developments in medical technology.

Improvements in health sector caused not only increasing life expectancy rates but also decreased infant mortality rates. While the world infant mortality rate was reported as 121.9 infants per 1000 live births in 1960, it was 31.7 infants in 2015 (World Bank, 2016). The number of infant deaths is less in developed countries than in developing countries. In consideration of the European region (especially in EU15), it was observed that mean infant mortality rate was recorded as 3.17 infants in 2014, which revealed great discrepancy in comparison with other world statistics (Eurostat, 2016).

The average life expectancy ratio was reported in the range of 70-79.9 years for 2015 in the European Union, including Turkey (Eurostat, 2016). These improvements might introduce various problems especially in the European Union. If the proportion of life in good health does not change, the public expenditure on health care is expected to increase from $0.7 \%$ of GDP in 2007 to $7.4 \%$ in 2060 (WHO, 2013:83). This is because the European region has significantly higher elder population. However, in consideration of improvements in health conditions, this could emerge as a factor that increases labor productivity. So improving productivity upgrades the opportunities for gainful production and admits on an increase in income. On the other hand, the cost of lost productivity might be several times greater than public expenditure on health care.

The aim of this study is to investigate the effect of health (life expectancy and mortality rate) on income in 16 countries (EU15 and Turkey) by using dynamic panel regression methods for period 1970-2013. The paper was organized as follows. In Section 2 and 3, theoretical framework and literature summary were presented. In Section 4, an empirical analysis was conducted. In Section 5, acquired results and suggestions were shared. And finally, conclusion was presented. This study also aims to emphasize the effects of the improving health conditions on the economic dimension and income as well as the human dimension.

\section{Theoretical Framework}

Since health is a form of a human capital, like educational infrastructure and cognitive attainment, it is associated with labor market success (Bhargava, 1998; Strauss \& Thomas, 
1998:766). So if human productivity increases because of health improvements, economic performance will raise (Narayan et al., 2010). This finding enlarges the policy priority of health in development; not only is health a major goal in itself, but it has an important impact on income and growth levels as well (Todaro \& Smith, 2012:400).

Potential transition channels between health and growth prepared with the study of Arora (2001) and our contributions were displayed in Figure 1. The development in health theoretically affects the population, life expectancy, and mortality rate, which constitutes a human capital accumulation of the country. Eventually, changes in human capital accumulation have an impact on the growth of countries because of productivity.

The educated, young and strong human capital is an important growth driver, so growth rate also depends on life expectancy (Barro, 1989; Becker et al., 1994:325; Croix \& Licandro, 1999:256). However, countries with greater life expectancy rates cannot increase the education of the major cohorts of children that survived because of bottlenecks in their education systems (Acemoğlu \& Johnson, 2007:957). From the educational point of view, it is necessary for the countries to complete the infrastructure development in order to increase their economic growth with huge life expectancy.

Figure 1: Potential Transition Channels between Health and Growth

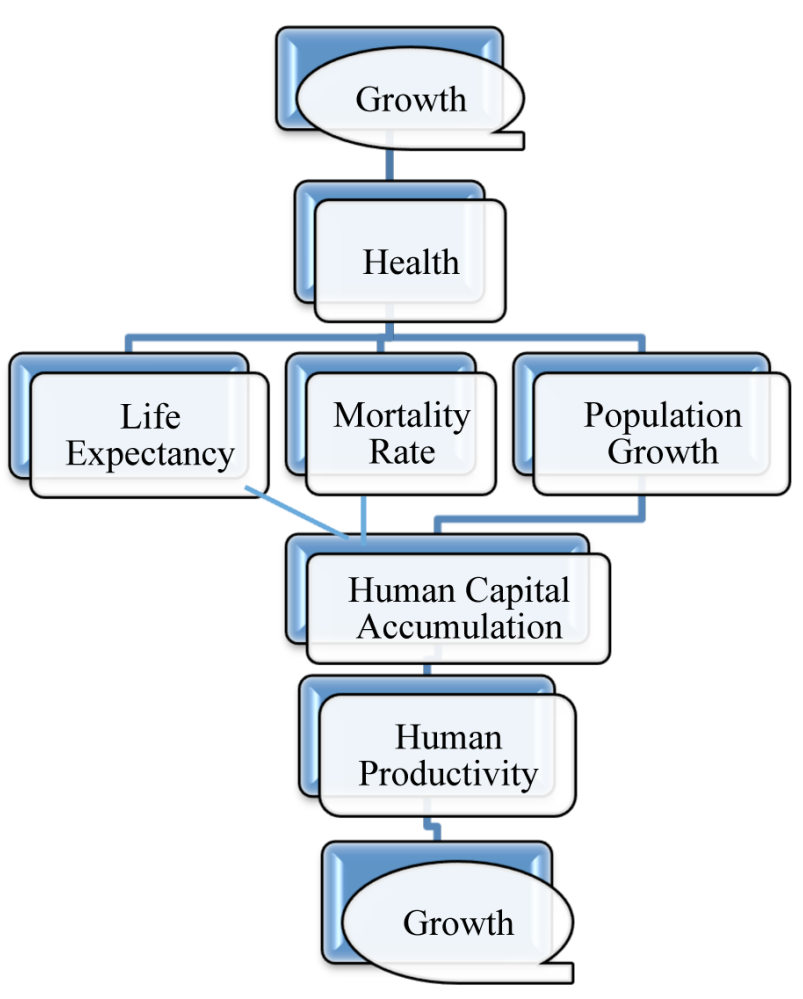


Many developing countries have had remarkable successes in reducing infant mortality rates. Mortality declined due to both better nutrition and health conditions. In this context, the decrease in mortality is seen as a component that increases human capital accumulation by raising education conditions and human abilities (Kalemli-Ozcan et al., 2000:2). The correct and efficient use of human capital accumulation increases the impact of physical-capital accumulation on income and growth (Mankiw et al., 1990:13).

In this context, there is no conclusive attest that a significant increase in life expectancy and mortality causes to a significant increase in per capita economic growth. "These results confirmed that global efforts to combat poor health conditions in less developed countries can be highly effective, but also shed doubt on claims that unfavorable health conditions are the root cause of the poverty of some nations" (Acemoğlu \& Johnson, 2007:925). For this reason, the effects of life expectancy and mortality rates on the economic growth should be applied to empirical and cross-country comparisons analysis.

\section{Literature Overview}

Life expectancy and mortality are universally viewed as important population health indicators (ART-CC, 2008:293; Todaro \& Smith, 2012:45). If the countries have high life expectancy and low mortality rates, it means that they have superior human capital (Arora, 2001). Countries with advanced human capital also have higher proportions of physical investment to GDP and their fertility rates fell (Barro, 1989:2).

Numerous studies in the literature examine whether health affects income indicators such as GDP, GDP per capita, GDP growth rate. Large number of these studies concludes that health has a positive and statistically significant impact on income indicators. This section is an overview of literature analyzing the empirical relationship between health and income. Since empirical results in literature generally indicate positive relation, literature survey is categorized by chronology, not the direction of relation between the variables.

Table 1 summarizes a sample of most referred studies.

Besides these abovementioned literatures in Table 1, there are another more recent empirical studies focusing on relation between health and income indicators. Bakare \& Sanmi (2011) have analyzed the link between health care expenditures and economic growth in Nigeria in the period $1970-2008$ by the ordinary least squares multiple regression analytical method. The results show that there is a significant and positive relationship between health care expenditures and economic growth.

Djafar \& Husaini (2011) have applied a co-integration and Granger causality test for 25 Asian countries. The study pointed out that GDP and life expectancy are co-integrated in 17 countries and bi-directional causality between GDP and life expectancy does not occur in the short-run but it occurs in 5 countries in the long run. 
Table 1: Summary of Empirical Literature

\begin{tabular}{|c|c|c|c|c|}
\hline Author(s) & Period & Country & Methodology & Result \\
\hline $\begin{array}{l}\text { Rivera \& } \\
\text { Currais } \\
(1999)\end{array}$ & $\begin{array}{c}1960- \\
1990\end{array}$ & OECD & OLS & $\begin{array}{l}\text { Health affects income growth } \\
\text { positively and significantly. } \\
\text { Existence of a feedback effect is } \\
\text { confirmed by Hausman test. }\end{array}$ \\
\hline $\begin{array}{l}\text { Bhargava } \\
\text { et al. } \\
(2001)\end{array}$ & $\begin{array}{c}1965- \\
1990\end{array}$ & $\begin{array}{l}\text { Developed and } \\
\text { developing } \\
\text { countries }\end{array}$ & OLS & $\begin{array}{l}\text { Health has a positive and } \\
\text { significant impact on GDP } \\
\text { growth. }\end{array}$ \\
\hline $\begin{array}{l}\text { Bloom et } \\
\text { al. }(2004)\end{array}$ & $\begin{array}{c}1960- \\
1990\end{array}$ & 104 countries & $\begin{array}{c}\text { Nonlinear } \\
\text { Two- Stage } \\
\text { Least Squares }\end{array}$ & $\begin{array}{c}\text { Health has a positive and } \\
\text { statistically significant effect on } \\
\text { growth rate of GDP. }\end{array}$ \\
\hline $\begin{array}{l}\text { Gyimah- } \\
\text { Brempong } \\
\text { \& Wilson } \\
(2004)\end{array}$ & $\begin{array}{l}20 \text { year } \\
\text { period } \\
35 \text { year } \\
\text { period }\end{array}$ & $\begin{array}{l}\text { Sub-Saharan } \\
\text { African } \\
\text { OECD }\end{array}$ & GMM & $\begin{array}{c}\text { Growth rate is strongly and } \\
\text { positively influenced by the } \\
\text { human capital. }\end{array}$ \\
\hline $\begin{array}{l}\text { Taban } \\
(2006)\end{array}$ & $\begin{array}{l}1968- \\
2003\end{array}$ & Turkey & $\begin{array}{c}\text { Granger } \\
\text { Causality and } \\
\text { Johansen Co- } \\
\text { integration }\end{array}$ & $\begin{array}{l}\text { Bidirectional causality and } \\
\text { co-integration has been found } \\
\text { between the health indicators and } \\
\text { income. }\end{array}$ \\
\hline $\begin{array}{l}\text { Li \& } \\
\text { Huang } \\
(2009)\end{array}$ & $\begin{array}{l}1978- \\
2005\end{array}$ & China & OLS & $\begin{array}{c}\text { Health has positive and } \\
\text { significant effects on economic } \\
\text { growth. }\end{array}$ \\
\hline $\begin{array}{l}\text { Narayan } \\
\text { et al. } \\
(2010)\end{array}$ & $\begin{array}{l}1974- \\
2007\end{array}$ & $\begin{array}{c}5 \text { Asian } \\
\text { Countries }\end{array}$ & DOLS & $\begin{array}{l}\text { There is statistically significant } \\
\text { and positive impact of health on } \\
\text { per capita income in the long run. }\end{array}$ \\
\hline $\begin{array}{l}\text { Baltagi \& } \\
\text { Moscone } \\
(2010)\end{array}$ & $\begin{array}{l}1971- \\
2004\end{array}$ & $\begin{array}{l}20 \text { OECD } \\
\text { Countries }\end{array}$ & $\begin{array}{l}\text { Spatial MLE, } \\
\text { FE and CCEP }\end{array}$ & $\begin{array}{l}\text { The long run relation between } \\
\text { health care expenditure and } \\
\text { income is positive. Health care is } \\
\text { necessity rather than a luxury. }\end{array}$ \\
\hline
\end{tabular}

Elmi \& Sadeghi (2012) have investigated the causality and co-integration relationships between economic growth and health care expenditures by using panel co-integration and causality in VECM framework over the period 1990-2009 for developing countries. The analysis shows that there is not observed any short-run causality from health spending to economic growth. However there is bilateral causality and long-run relationship.

Tekabe (2012) has explored relation between health level and GDP per capita and indicated that productivity is influenced in a positive way by health level. In addition to this, analysis shows that income makes a positive impact on health level. In other words, there is a bidirectional relationship health level and income; hence the low income countries of Africa South of the Sahara should give a priority to health investment. 
Rhee (2014) has explored the effect of healthcare expenditure on national income. The sample period is 1995-2009 and the sample is world economies classified as high income, middle income and low income economies by World Bank. According to the results of this study, healthcare expenditure consistently and positively affects national income in most cases.

Kurt (2015) has analyzed the direct and external effects of health expenditures on economic growth in Turkey in the period 2006-2013 using monthly data by using Feder-Ram model. The analysis shows that the direct impact of government health expenditure on economic growth is positive and significant. Besides that, indirect impact is negative and significant.

Murthy \& Okunade (2016) have examined determinants of U.S. health expenditure by using 1960-2012 annual time series data. The study has applied the ARDL approach to identify the main drivers. The empirical findings show that per capita real income, the population percent above 65 years and the level of health care technology are cointegrated. Income has positive effect on U.S. health expenditure per capita.

Compared to the extensive literature on relationship between health and income indicators across the countries, empirical literature on relationship between health and income comparing EU and Turkey is not available. Due to this gap, this study makes a contribution through compare EU15 and Turkey by examining whether there is a relationship between health and income. By the way of comparing countries, we also offer some policy implications for Turkey.

\section{The Model Specification and Data}

In order to test the relationship between income and health, the following equation was estimated.

$$
G D P_{i t}=\beta_{0}+\beta_{1} H E A_{i t}+\varepsilon_{i t}
$$

where $G D P_{i t}$ and $H E A_{i t}$ imply measures for income per capita and health, respectively and $\varepsilon_{i}$ is error term. This study covers 16 countries (EU15 and Turkey) for the period between 1970 and 2013 as a panel data set ${ }^{1}$. The dependent variable is GDP per capita. Two types of health data are used in estimations: life expectancy at birth and mortality rate.

- GDP per capita (constant 2005US \$) (GDP) is the measure of economic performance and compiled from World Bank Development Indicators online database.

- Life Expectancy at Birth Total Years (LIFE) is the number of years a newborn infant would live if prevailing patterns of mortality at the time of its birth were to stay the same throughout its life and is compiled from World Bank Development Indicators online database.

- Mortality Rate Infant per 1000 live births (MOR) is the number of infants dying before reaching one year of age per 1000 live births in a given year and compiled from World Bank Development Indicators online database.

1 Data covers 1970 to 2013 period for the following 15 EU countries and Turkey: Austria, Belgium, Denmark, Finland, France, Germany, Greece, Ireland, Italy, Luxembourg, Netherland, Portugal, Spain, Sweden, United Kingdom and Turkey. 
In Table 2, the mean, the minimum, the maximum, standard deviation of series and the number of observation are presented as fundamental descriptive statistics. In addition to this, sample correlations are given in Table 3.

Table 2: Descriptive Statistics of Data

\begin{tabular}{cccccc}
\hline Variables & Mean & Minimum & Maximum & Standard Deviation & Observations \\
\hline GDP & 10.09 & 8.05 & 11.38 & 0.57 & 704 \\
\hline LIFE & 4.32 & 3.95 & 4.41 & 0.06 & 704 \\
\hline MOR & 2.10 & 0.47 & 4.83 & 0.78 & 704 \\
\hline
\end{tabular}

Note: All series are in their natural logs.

Table 3: Pairwise Correlation

\begin{tabular}{cccc}
\hline & GDP & LIFE & MOR \\
\hline GDP & 1 & - & - \\
\hline LIFE & 0.78 & 1 & - \\
\hline MOR & -0.86 & -0.91 & 1 \\
\hline
\end{tabular}

In the light of the information given above, our paper represents an attempt to estimate the following equations;

$$
\begin{aligned}
& G D P_{i t}=\theta+\varphi L I F E_{i t}+u_{i t} \\
& G D P_{i t}=\alpha+\omega M O R_{i t}+\vartheta_{i t}
\end{aligned}
$$

Throughout the paper the size, sign and significance of the two coefficients, $\phi$ and $\omega$, will be analyzed.

\section{The Method and Findings}

The empirical modeling framework of this study consists of four steps. First of all, the significance of correlations among cross section residuals is examined. This step aims to provide answer to the following question: Does a shock in a country spillover on other countries? Secondly, stationary of variables are analyzed by using panel unit root tests and the order of integration of the variables is shown. Thirdly, the co-integration relationship is examined to determine whether a long run equilibrium relationship exists among the nonstationary variables in level form. Lastly, long run co-integration parameters are estimated.

\subsection{Cross Sectional Dependence}

One important issue to be considered in a panel data analysis is to examine the existence of cross sectional dependence across countries. This is because a shock that affects one country may spillover on other countries. Due to highly integrated economic relations and high degree 
of globalization, empirical analysis starts with examining the significance of cross sectional correlations among residuals before applying unit root tests.

The tests for cross sectional dependence can be carried out by using the Breusch \& Pagan (1980), Pesaran (2004) and Pesaran, Ullah \& Yamagata (2008) LM test statistics. The Breusch \& Pagan LM test is based on the sum of squared coefficients of correlation among cross sectional residuals obtained through OLS. The test statistic denoted as $C D_{L M I}$ is calculated as follows;

$$
C D_{L M 1}=T \sum_{i=1}^{N-1} \sum_{j=i+1}^{N} \widehat{\rho}_{i j}^{2} \sim X_{\frac{N(N-1)}{2}}^{2}
$$

However, this test statistic is not applicable with large $N$. In order to solve this problem, Pesaran (2004: 5) developed the following test statistic:

$$
C D_{L M 2}=\sqrt{\frac{1}{N(N-1)}} \sum_{i=1}^{N-1} \sum_{j=i+1}^{N} T\left(\widehat{\rho}_{i j}^{2}-1\right) \sim N(0,1)
$$

This test has asymptotic standard normal distribution with first $T \rightarrow \infty$ and then $N \rightarrow \infty$. In addition to this, Pesaran (2004:5) proposed the following cross-sectionally dependency test when $\mathrm{N}$ is large and $\mathrm{T}$ is small.

$$
C D_{L M 3}=\sqrt{\frac{2 T}{N(N-1)}} \sum_{i=1}^{N-1} \sum_{j=i+1}^{N}\left(\widehat{\rho}_{i j}^{2}\right) \sim N(0,1)
$$

$C D_{L M 3}$ test statistic asymptotic standard normal distribution with $T \rightarrow \infty$ and $N \rightarrow \infty$ in any order.

All test statistics with the corresponding probabilities are shown in Table 4.

Table 4: Cross-Sectional Dependence

\begin{tabular}{cccc}
\hline & $C D_{L M 1}$ & $C D_{L M 2}$ & $C D_{L M 3}$ \\
\hline \multirow{2}{*}{ GDP } & $272.04 * * *$ & $9.81^{* * *}$ & $-2.50^{* * *}$ \\
& $(0.00)$ & $(0.00)$ & $(0.00)$ \\
\hline \multirow{2}{*}{ LIFE } & $221.16^{* * *}$ & $6.53 * * *$ & $-2.98 * * *$ \\
& $(0.00)$ & $(0.00)$ & $(0.00)$ \\
\hline \multirow{2}{*}{ MOR } & $246.83^{* * *}$ & $8.18^{* * *}$ & $-3.73 * * *$ \\
& $(0.00)$ & $(0.00)$ & $(0.00)$ \\
\hline \multirow{2}{*}{ Eq. (7) } & $1418.85^{* * *}$ & $83.84 * * *$ & $26.94 * * *$ \\
& $(0.00)$ & $(0.00)$ & $(0.00)$ \\
\hline \multirow{2}{*}{ Eq. (8) } & $908.91^{* * *}$ & $50.92 * * *$ & $22.04 * * *$ \\
& $(0.00)$ & $(0.00)$ & $(0.00)$ \\
\hline
\end{tabular}

Note: $* * *, * *$ and $*$ stand for significance at 1,5 and $10 \%$ levels, respectively. Numbers in brackets are p-values. 
The results indicate that the null hypothesis of no cross sectional dependence is rejected. That is, there is a strong evidence on the existence of the cross sectional dependence across countries (EU15 and Turkey). Due to highly integrated economic relations among 16 countries, this result is consistent with our expectations.

Moreover, this finding simply implies that panel unit root and co-integration tests that do not take into account cross sectional dependence results in misleading inferences. Thus, the second generation panel unit root and co-integration tests allowing for the cross sectional dependence will be used in the remaining empirical sections.

\subsection{Panel Unit Root Test}

In order to find the order of integration of the variables, Hadri \& Kurozumi (2012) and Breuer et al. (2001) panel unit root tests will be performed.

The paper by Hadri \& Kurozumi (2012:32) proposes two test statistics. In order to calculate first test statistic, they first estimate the $A R(p)$ model augmented by lags of $\bar{y}_{t}$ for each $i$ by the least squares method and construct the estimator of the long run variance by;

$$
\widehat{\sigma}_{i S P C}^{2}=\frac{\widehat{\sigma}_{v i}^{2}}{\left(1-\widehat{\phi}_{i}\right)^{2}}
$$

where $\widehat{\phi}_{i}=\min \left(1-\frac{1}{\sqrt{T}}, \sum_{j=1}^{p} \widehat{\phi}_{i j}\right)$ and $\widehat{\sigma}_{v i}^{2}=\frac{1}{T} \sum_{t=1}^{T} \widehat{v}_{i t}^{2}$. They then propose constructing the test statistic denoted as $Z A_{A}^{S P C}$.

$$
S T_{i}^{S P C}=\frac{1}{\widehat{\sigma}_{i S P C}^{2} T^{2}} \sum_{t=1}^{T}\left(S_{i t}^{w}\right)^{2}
$$

The second test statistic is based on lag augmented method. At this point, they estimate $A R(p+1)$ model instead of $A R(p)$ model then construct the test statistic denoted as $Z A_{A}^{L A}$.

$$
\begin{aligned}
& S T_{i}^{L A}=\frac{1}{\widehat{\sigma}_{i L A}^{2} T^{2}} \sum_{t=1}^{T}\left(S_{i t}^{w}\right)^{2} \\
& \quad \text { where } \widehat{\sigma}_{i L A}^{2}=\frac{\widehat{\sigma}_{i L A}^{2}}{\left(1-\breve{\phi}_{i 1}-\ldots-\breve{\phi}_{i p}\right)^{2}}
\end{aligned}
$$

It is important to note that $(i)$ in Hadri \& Kurozumi (2012:31) approach the null hypothesis is stationary rather than nonstationary, (ii) this test can also be applied in heterogeneous panel data with cross sectional dependence in the form of a common factor, (iii) it also allows for serial correlation.

On the other hand, the seemingly unrelated regression augmented Dickey Fuller (SURADF) test of Breuer et al. (2001:487) which is based on the panel estimation method of unrelated regression presents the system of $\mathrm{ADF}$ equations to be estimated;

$$
\Delta y_{i t}=\alpha_{i}+\beta_{i} y_{i t-1} \delta_{i} t \sum_{j=1}^{p_{j}} \phi_{i j} \Delta y_{i t-1}+u_{i t}
$$


Once Eq. (15) is estimated by SUR, the test statistics can be computed by using t-ratios of first order autoregressive coefficients. Due to the fact that distribution of test statistics is nonstandard, the critical values are obtained from Monte Carlo distribution individually.

In contrast to Hadri \& Kurozumi (2012), SURADF (2001: 482) approach tests a separate unit root hypothesis for each individual panel member and therefore, allows the researcher to discern which series are $I(0)$ and which ones are $I(1)$.

In this study, while Hadri \& Kurozumi (2012) is applied to get panel unit root results (one test statistic for all countries), SURADF (2001:487) is applied to get individual panel member (one test statistic for each country) unit root results. Hence, these tests can be regarded as complementary to each other.

Hadri \& Kurozumi (2012) and SURADF (2001) unit root test results are illustrated in Table 5 and 6 , respectively. The results of the SURADF test using critical values are also presented in Table 6.

Table 5: Hadri \&Kurozumi Unit Root Test

\begin{tabular}{cccc}
\hline & GDP & LIFE & MOR \\
\hline \multirow{2}{*}{$Z_{A}^{S P C}$} & $3.78 * * *$ & $21.70 * * *$ & $32.49 * * *$ \\
& $(0.00)$ & $(0.00)$ & $(0.00)$ \\
\hline \multirow{2}{*}{$Z_{A}^{L A}$} & $4.04 * * *$ & $834.87 * * *$ & $378.94 * * *$ \\
& $(0.00)$ & $(0.00)$ & $(0.00)$ \\
\hline
\end{tabular}

Note: $* * *, * *$ and $*$ stand for significance at 1,5 and $10 \%$ levels, respectively. Null hypothesis is stationary.

It is clearly seen that the panel test result (presented in Table 5) is in agreement with the individual unit root tests (presented in Table 6). In other words, unit root cannot be rejected for the panel as a whole and panel members. While, Hadri \& Kurozumi (2012) test indicates that null hypothesis of no unit root is rejected at the $1 \%$ significance level, namely, there is strong evidence on the existence of unit root for the panel as a whole, SURADF test implies that null hypothesis of unit root is accepted for each panel countries at the $1 \%$ significance level.

This evidence suggests that the variables (GDP, LIFE, and MOR) do evolve as nonstationary processes and the OLS estimation of Eq. (2) and Eq. (3) may result in biased and inconsistent inferences. Thus, we now turn to panel co-integration techniques to determine whether a long run equilibrium relationship exists among the non-stationary variables in level form. 
Table 6: SURADF Unit Root Test

\begin{tabular}{ccccccc}
\hline Countries & GDP & $\begin{array}{c}\text { Critical } \\
\text { Value } \\
\mathbf{0 . 0 1}\end{array}$ & LIFE & $\begin{array}{c}\text { Critical } \\
\text { Value } \\
\mathbf{0 . 0 1}\end{array}$ & MOR & $\begin{array}{c}\text { Critical } \\
\text { Value } \\
\mathbf{0 . 0 1}\end{array}$ \\
\hline Austria & $-3.26(1)$ & -7.35 & $-2.08(1)$ & -6.90 & -3.26 & -6.01 \\
\hline Belgium & $-3.51(1)$ & -8.10 & $-2.43(2)$ & -11.96 & -1.64 & -9.16 \\
\hline Denmark & $-4.02(3)$ & -6.98 & $3.91(4)$ & -6.21 & -0.21 & -6.76 \\
\hline Finland & $-2.67(4)$ & -6.09 & $-1.86(1)$ & -6.86 & 0.26 & -5.82 \\
\hline France & $-4.05(1)$ & -7.39 & $-1.75(1)$ & -7.76 & -2.84 & -6.89 \\
\hline Germany & $-2.94(1)$ & -6.74 & $-1.14(1)$ & -7.03 & -6.57 & -6.65 \\
\hline Greece & $-2.83(1)$ & -7.48 & $-2.52(1)$ & -5.98 & -2.19 & -6.67 \\
\hline Ireland & $-2.04(1)$ & -6.03 & $1.12(1)$ & -5.34 & -1.97 & -6.85 \\
\hline Italy & $-5.40(1)$ & -7.07 & $-2.79(2)$ & -18.01 & -2.26 & -10.62 \\
\hline Luxembourg & $-2.08(1)$ & -6.31 & $-0.25(1)$ & -6.57 & 2.32 & -6.31 \\
\hline Netherland & $-2.56(1)$ & -8.35 & $-0.27(1)$ & -7.60 & 0.24 & -5.96 \\
\hline Portugal & $-2.88(1)$ & -9.01 & $-2.72(1)$ & -6.52 & -3.92 & -11.80 \\
\hline Spain & $-2.71(1)$ & -10.90 & $-1.92(1)$ & -7.03 & -1.40 & -8.41 \\
\hline Sweden & $-1.66(1)$ & -6.23 & $-0.57(2)$ & -11.46 & -1.16 & -6.07 \\
\hline Turkey & $-0.46(1)$ & -6.84 & $-3.47(1)$ & -20.08 & 4.24 & -8.13 \\
\hline Uni. King. & $-3.04(3)$ & -6.71 & $0.44(3)$ & -6.97 & -1.61 & -7.22 \\
\hline
\end{tabular}

Note: $* * *$ stand for significance at $1 \%$ level. The critical values for the SURADF test were generated using Monte Carlo Simulations with 1000 replication. The lag lengths are reported in parenthesis. The maximum lag lengths were set to 4 . Null hypothesis is nonstationary.

\subsection{Co-Integration Analysis}

The existence of co-integration relationship is examined by co-integration techniques proposed by Westerlund \& Edgerton (2007) and Westerlund (2008). The panel bootstrap co-integration test developed by Westerlund \& Edgerton (2007: 185) allows for dependence both within and between the cross sectional units. This co-integration approach tests the null hypothesis of co-integration against the alternative of no co-integration. The advantages of this test may be summarized as follows: ( $i$ ) the bootstrap test has good size accuracy in all experiments, (ii) the asymptotic test appears to be quite robust to the effects of cross sectional dependence, (iii) even though it tends to be slightly undersized, the raw power is quite high for the bootstrap test.

Westerlund (2008:195-203) proposes two panel co-integration tests that are based on applying the Durbin Hausman principle $\left(\hat{e}_{i t}=\phi_{i} \hat{e}_{i t-1}+\right.$ error $)$. The first, the panel test, is constructed under the maintained assumption that $\phi_{i}=\phi$ for all $\dot{I}$, while the second, the group mean test, is not. Both tests are composed of two estimators of $\phi_{i}$ that have different 
probability limits under the alternative hypothesis of co-integration but share the property of consistency under the null of no co-integration. The Durbin Hausman test statistics are as follows;

$$
\begin{aligned}
& D H_{g}=\sum_{i=1}^{n} \hat{S}_{i}\left(\hat{\phi}_{i}-\hat{\phi}_{i}\right)^{2} \sum_{t=2}^{T} \hat{e}_{i t-1}^{2} \\
& D H_{p}=\hat{S}_{n}(\hat{\phi}-\hat{\phi})^{2} \sum_{i=1}^{n} \sum_{t=2}^{T} \hat{e}_{i t-1}^{2}
\end{aligned}
$$

While panel statistic, $\mathrm{DH}_{p}$, is constructed by summing the $n$ individual terms before multiplying them together, the group mean statistic, $\mathrm{DH}_{g}$, is constructed by first multiplying the various terms and then summing (Westerlund, 2008:203).

Westerlund \& Edgerton (2007) and Westerlund (2008) co-integration test results are illustrated in Table 7.

Table 7: Westerlund \& Edgerton (2007) and Westerlund (2008)

\begin{tabular}{cccc}
\hline & & Eq. (2) & Eq. (3) \\
\hline Westerlund and & LM Statistic & 6.05 & 3.60 \\
Edgerton (2007) & Group Statistic & 0.19 & $(0.86)$ \\
\hline & $D H_{g}$ & $(0.42)$ & $5.08^{* * *}$ \\
Westerlund (2008) & Panel Statistic & $1.48^{*}$ & $(0.00)$ \\
\cline { 2 - 4 } & $D H_{p}$ & $(0.06)$ & $14.23^{* * *}$ \\
& & $(0.00)$ \\
\hline
\end{tabular}

Note: $* * *, * *$ and $*$ stand for significance at 1,5 and $10 \%$ levels, respectively.

Table 7 shows that only one of these test statistics (group test statistic for Eq. (2)) rejects co-integration relationship at the $10 \%$ significance level. Hence, LM statistic of Westerlund \& Edgerton (2007) can undoubtedly be taken as strong evidence in favor of co-integration relationship for all countries. However, there is an important distinction in the alternative hypotheses of group and panel statistics of Westerlund (2008:203). While the rejection of the null hypothesis of group statistic cannot be taken to suggest that all countries are co-integrated, the rejection of the null hypothesis of panel statistic can be interpreted as providing evidence in favor of co-integration for all countries, if the assumption of homogeneity of the autoregressive parameters holds. Hence, without testing the homogeneity of the autoregressive parameters, one can conclude that at least some of the countries are co-integrated even if panel statistics is used. Nevertheless, the homogeneity of the autoregressive parameters is directly related with data collection process rather than homogeneity tests. Thus, data set used in this study can provide strong evidence in favor of homogeneity of the auto regressive parameters due to similar economic, political and social structure and highly integrated economic relations between EU countries. 


\subsection{Estimation of Long Run Coefficients}

The long run individual co-integration coefficients are estimated with the Dynamic Seemingly Unrelated Co-integrating Regressions (DSUR) technique proposed by Mark et al. (2005:797). The purpose of using this method is that it takes into account the results obtained from analyses applied in previous sections. They can be listed as follows: DSUR is applicable for panel co-integration estimation in environments where the cross section is small $(\mathrm{N}=16)$ to the available time series $(\mathrm{T}=44)$ and in which the co-integration vector displays heterogeneity across equations and in which it is homogeneous. DSUR estimator is not feasible in systems of large $\mathrm{N}$ due to the proliferations of free parameters that must be estimated in the error correlation. It is also asymptotically efficient when the equilibrium errors exhibit cross sectional dependence. Table 7 reports the long run coefficient estimates.

Table 8: Dynamic Seemingly Unrelated Cointegrating Regression

\begin{tabular}{|c|c|c|c|c|}
\hline \multirow{2}{*}{ Country } & \multicolumn{2}{|c|}{ Eq. (2) } & \multicolumn{2}{|c|}{ Eq. (3) } \\
\hline & LIFE & Std. Error & MOR & Std. Error \\
\hline Austria & $5.489 * * *$ & 0.207 & $-0.387 * * *$ & 0.019 \\
\hline Belgium & $5.887 * * *$ & 0.176 & $-0.429 * * *$ & 0.009 \\
\hline Denmark & $11.301 * * *$ & 1.541 & $-0.555^{* * *}$ & 0.049 \\
\hline Finland & $7.131 * * *$ & 0.291 & $-0.568 * * *$ & 0.016 \\
\hline France & $4.853 * * *$ & 0.216 & $-0.449 * * *$ & 0.013 \\
\hline Germany & $5.351 * * *$ & 0.299 & $-0.381 * * *$ & 0.007 \\
\hline Greece & $3.775 * * *$ & 0.606 & $-0.211 * * *$ & 0.048 \\
\hline Ireland & $12.227 * * *$ & 0.626 & $-0.784 * * *$ & 0.066 \\
\hline Italy & $5.075^{* * *}$ & 0.320 & $-0.344 * * *$ & 0.018 \\
\hline Luxembourg & $8.220 * * *$ & 0.500 & $-0.562 * * *$ & 0.042 \\
\hline Netherland & $8.909 * * *$ & 0.543 & $-0.590 * * *$ & 0.026 \\
\hline Portugal & $5.590 * * *$ & 0.466 & $-0.312 * * *$ & 0.018 \\
\hline Spain & $6.335 * * *$ & 0.628 & $-0.396 * * *$ & 0.041 \\
\hline Sweden & $6.776^{* * * *}$ & 0.296 & $-0.470 * * *$ & 0.023 \\
\hline Turkey & $2.641 * * *$ & 0.244 & $-0.423 * * *$ & 0.017 \\
\hline Uni. King. & $7.838 * * *$ & 0.287 & $-0.556 * * *$ & 0.018 \\
\hline Panel & $5.357 * * *$ & 0.155 & $-0.411 * * *$ & 0.006 \\
\hline
\end{tabular}

Note: $* * *, * *$ and $*$ stand for significance at 1,5 and $10 \%$ levels, respectively.

According to Table 8, panel coefficients presented in the last row suggest that while there is positive and statistically significant relationship between income and life expectancy at birth, there is negative and statistically significant relationship between income and mortality rate. More specifically, while a $\% 1$ increase in life expectancy at birth increases income by $\% 5.35$, a $\% 1$ decrease in mortality rate increases income by $\% 0.41$. Findings suggest that life expectancy at birth is more pronounced than mortality rate in explaining income. 
Moreover, the individual coefficients are in agreement with the panel coefficients and all empirical results (in terms of sign) are consistent with theoretical expectations. As shown in Table 8, an incline in life expectancy at birth results in higher income in relatively more developed countries such as Denmark, Finland, Luxembourg, Ireland and United Kingdom. However, this effect decreases in magnitude in developing countries such as Turkey. While a $\% 1$ increase in life expectancy at birth in Denmark increases income by $\% 11.3$, a $\% 1$ increase in life expectancy at birth in Turkey increases income by \%2.64. Similarly, the effect of mortality rate on income is negative and higher in developed countries compared with developing countries. Specifically, while a $\% 1$ decrease in mortality rate increase income in Ireland and Denmark by $\% 0.78$ and $\% 55$, respectively, a $\% 1$ decrease in mortality rate increases income in Turkey by $\% 4.2$.

\subsection{Robustness Analysis of the Results}

The robustness analysis extends the coverage of the data for another decade from 19602013 for 13 out of the 16 countries $^{2}$ in the original sample. The results from this exercise are presented in Table $9^{3}$.

Table 9: Dynamic Seemingly Unrelated Cointegrating Regression

\begin{tabular}{|c|c|c|c|c|}
\hline \multirow{2}{*}{ Country } & \multicolumn{2}{|c|}{ Eq. (2) } & \multicolumn{2}{|c|}{ Eq. (3) } \\
\hline & LIFE & Std. Error & MOR & Std. Error \\
\hline Austria & $6.160 * * *$ & 0.628 & $-0.463 * * *$ & 0.021 \\
\hline Belgium & $6.562 * * *$ & 0.550 & $-0.489 * * *$ & 0.020 \\
\hline Denmark & 6.262 & 7.030 & $-0.522 * * *$ & 0.033 \\
\hline Finland & $7.270 * * *$ & 0.431 & $-0.606 * * *$ & 0.014 \\
\hline France & $5.596 * * *$ & 0.508 & $-0.521 * * *$ & 0.023 \\
\hline Greece & $4.608 * * *$ & 0.950 & $-0.358 * * *$ & 0.038 \\
\hline Italy & $5.653 * * *$ & 0.661 & $-0.392 * * *$ & 0.022 \\
\hline Netherland & $9.918 * * *$ & 0.782 & $-0.681 * * *$ & 0.020 \\
\hline Portugal & $6.302 * * *$ & 0.479 & $-0.388 * * *$ & 0.024 \\
\hline Spain & $6.810 * * *$ & 0.752 & $-0.471 * * *$ & 0.014 \\
\hline Sweden & $7.303 * * *$ & 0.464 & $-0.474 * * *$ & 0.017 \\
\hline Turkey & $2.522 * * *$ & 0.234 & $-0.472 * * *$ & 0.014 \\
\hline Uni. King. & $8.039 * * *$ & 0.438 & $-0.593 * * *$ & 0.014 \\
\hline Panel & $4.765^{* * *} *$ & 0.209 & $-0.461 * * *$ & 0.010 \\
\hline
\end{tabular}

Note: $* * *, * *$ and $*$ stand for significance at 1,5 and $10 \%$ levels, respectively.

2 Data covers 1960 to 2013 period for the following 12 EU countries and Turkey: Austria, Belgium, Denmark, Finland, France, Greece, Italy, Netherland, Portugal, Spain, Sweden, United Kingdom and Turkey.

3 We also examine cross sectional dependence across countries, stationary of variables and co-integration relationship among non-stationary variables. However, to save space, we have not included these results in the paper. These results are available from the authors upon request. 
These results presented in Table 9 are consistent with the results illustrated in Table 8. In general, looking at the estimates of Eq. (2) and Eq. (3) presented in Table 9, the noticeable differences from the baseline results are as follows: (i) the coefficient estimates of life expectancy at birth increase in magnitude in all cases except Turkey and Denmark; (ii) the coefficient estimate of Denmark is now statically insignificant at the $\% 10$ level; (iii) the coefficient estimate of life expectancy at birth for panel as a whole decreases in magnitude from 5.357 to 4.765 but remains statistically significant at the $\% 1$ level; (iv) the coefficient estimates of mortality rate increase in magnitude in all cases except Denmark; $(v)$ the coefficient estimate mortality rate for panel as a whole increases in magnitude from 0.411 to 0.461 but remains statistically significant.

\section{Conclusion}

Economists have long debated whether health promotes income. In this study, the relationship between health and income was analyzed over the period 1970-2013 for the EU15 and Turkey. Last section of our paper is also devoted to checking the robustness of our central results and estimates our model for different sample: 1960-2013 and 13 out of the 16 countries. In all cases, the empirical results are robust and tell a similar story that health plays significant role in income and the impact of health on income varies across countries due to the heterogeneous of economic structures.

More clearly, the empirical evidence shows that health has positive impact on income in two health measures, life expectancy at birth and mortality rate. Our results are consistent with the findings of Rivera \& Currais (1999), Bhargava et al. (2001), Bloom et al. (2004), Narayan et al. (2010), Baltagi \& Moscone (2010). The estimates also indicate that the relationship is even stronger for EU15 compared with Turkey.

Empirical results have also a particular significance regarding Turkey's accession process to the EU. Turkey has been a candidate for EU membership since 1999 and accession negotiations started in 2005. In the accession process, one of the 13 chapters is directly related to health. Hence, we can conclude that health has always been considered as an important part of the full membership of Turkey due to its critical role in economic efficiency and policy.

All empirical results are important not only because they provide new evidence in favor of health, but also because they provide information to policy makers in which health contributes income in a particular type of economy. The results suggest some policy implications.

The first policy implication is that relatively less developed countries, i.e. Greece and Turkey, should invest more in health to increase their income. If these countries are in better position to improve health, the impact of health on income in magnitude will be higher in these countries.

The second important policy implication is specific to Turkey-EU relations. Turkey has come a long way in the process of harmonization with the EU acquis in the field of health. However, the economic effects of these developments have not yet been fully realized. So, Turkey should put into effect economic, social and health policies to increase life expectancy and standard of living, to reduce health level differences between regions and income groups, as soon as possible. 


\section{References}

Acemoğlu, D. \& Johnson, S. (2007). Disease and development: The effect of life expectancy on economic growth. Journal of Political Economy, 115(6), 925-985.

ART-CC. (2008). Life expectancy of individuals on combination antiretroviral therapy in highincome countries: a collaborative analysis of 14 cohort studies. The Lancet, 372(9635), 293-299.

Arora, S. (2001). Health, human productivity, and long-term economic growth. The Journal of Economic History, 61(3), 699-749.

Bakare, A. S. \& Sanmi, O. (2011). Health care expenditure and economic growth in Nigeria: An empirical study. Journal of Emerging Trends in Economics and Management Sciences, 2(2), 83-87.

Baltagi, B. H. \& Moscone, F. (2010). Health care expenditure and income in the OECD reconsidered: Evidence from panel data. Economic Modelling, 27, 804-811.

Barro, R. J. (1989). Economic growth in a cross section of countries. National Bureau of Economic Research, No. w3120.

Becker, G. S., Kevin, M. M. \& Robert, T. (1994). Human capital, fertility, and economic growth. Human Capital: A Theoretical and Empirical Analysis with Special Reference to Education, (3rd Ed., pp. 323-350). The University of Chicago Press.

Bhargava, A. (1998). A dynamic model for the cognitive development of Kenyan schoolchildren. Journal of Educational Psychology, 90(1), 162.

Bhargava, A., Jamison, D.T., Lau, L. \& Murray, C. J. (2001). Modeling the effects of health on economic growth. Journal of Health Economics, 20(3), 423-440.

Bloom, D. E., Canning, D. \& Sevilla, J. (2004). The effect of health on economic growth: A production function approach. World Development, 32(1), 1-13.

Breuer, J. B., McNown, R. \& Wallace, M. S. (2001). Misleading inferences from panel unitroot tests with an illustration from purchasing power parity. Review of International Economics, 9(3), 482-493.

Breusch, T. \& Adrian, P. (1980). The Lagrange multiplier test and its applications to model specification tests in econometrics. Review of Economic Studies, 47, 239-53.

Djafar, F. \& Husaini, D. H. (2011). The nexus between health and economic growth in selected Asian countries. International Journal of Business and Society, 12(2), 109-126.

Elmi, Z. M. \& Sadeghi, S. (2012). Health care expenditures and economic growth in developing countries: panel co-integration and causality. Middle-East Journal of Scientific Research, 12(1), 88-91.

Eurostat. (2016). Retrieved December 22, 2016, from http://appsso.eurostat.ec.europa.eu/nui / show.do?dataset=demo_minfind\&lang=en

Gyimah-Brempong, K. \& Wilson, M. (2004). Health human capital and economic growth in Sub-Saharan African and OECD countries. The Quarterly Review of Economics and Finance, 44, 296-320. 
Hadri, K. \& Kurozumi, E. (2012). A simple panel stationarity test in the presence of serial correlation and a common factor. Economics Letters, 115, 31-34.

Kalemli-Ozcan, S., Ryder, H.E.\& Weil, D.N. (2000). Mortality decline, human capital investment, and economic growth. Journal of Development Economic, 62(1), 1-23.

Kurt, S. (2015). Government health expenditures and economic growth: A Feder-Ram approach for the case for Turkey. International Journal of Economics and Financial Issues, 5(2), 441-447.

Li, H. \& Huang, L. (2009). Health, education and economic growth in China: Empirical findings and implications. China Economic Review, 20, 374-387.

Mankiw, N. G., Romer, D. \& Weil, D. N. (1992). A contribution to the empirics of economic growth. The Quarterly Journal of Economics, 107(2), 407-437.

Mark, N. C., Ogaki, M. \& Sul, D. (2005). Dynamic seemingly unrelated co-integrating regressions. Review of Economic Studies, 72, 797-820.

Murthy, V.N.R. \& Okunade, A. A. (2016). Determinants of U.S. health expenditure: Evidence from autoregressive distributed lag (ARDL) approach to co-integration. Economic Modelling, 59, 67-73.

Narayan, S., Narayan, P. K. \& Mishra, S. (2010). Investigating the relationship between health and economic growth: empirical evidence from a panel of 5 Asian countries. Journal of Asian Economics, 21, 404-411.

Pesaran, M. H. (2004). General diagnostic tests for cross section dependence in panels. Cambridge Working Papers in Economics, 435.

Pesaran, M. H., Ullah, A. \& Yamagata, T. (2008). A bias-adjusted $1 \mathrm{~m}$ test of error cross-section independence. Econometrics Journal, 11, 105-127.

Rhee, H. J. (2014). Effects of healthcare expenditure on national income: A rational expectation approach. Advanced Science and Technology Letters, 70, 19-23.

Rivera, B. \& Currais, L. (1999). Economic growth and health: Direct impact or reverse causation? Applied Economics Letters, 6(11), 761-764.

Strauss, J. \& Duncan, T. (1998). Health, nutrition, and economic development. Journal of Economic Literature, 36(2), 766-817.

Taban, S. (2006). Türkiye'de sağlık ve ekonomik büyüme arasındaki nedensellik ilişkisi. Sosyoekonomi, 2, 31-46.

Tekabe, L. F. (2012). Health and long run economic growth in selected low income countries of Africa South of the Sahara: Cross country panel data analysis, Student Thesis, 1-59, Södertörns University Department of Social Sciences.

Todaro, M. P. \& Smith, S. (2012). Economic development.11th Edition, USA Boston: Pearson Education, Inc.

Westerlund, J. \& Edgerton, D. L. (2007). A panel bootstrap co-integration test. Economic Letters, 97(3), 185-190.

Westerlund, J. (2008). Panel co-integration tests of the Fisher effect. Journal of Applied Econometrics, 23, 193-233. 
World Bank. (2016). Retrieved October 1, 2016, from http://data.worldbank.org/data-catalog/ world-development-indicators

WHO. (2013). Research for universal health coverage: World health report 2013. Retrieved November 21, 2016, from http://www.who.int/whr/2013/report/en/

WHO. (2016). Life expectancy increased by 5 years since 2000, but health inequalities persist. Retrieved November 21, 2016, from http://www.who.int/mediacentre/news/ releases/2016/health-inequalities-persist/en/ 